\title{
COMPLEX THERAPY OF ATOPIC CHEILITIS
}

\author{
Nataliya M. Ilenko, Ella V. Nikolishyna, Iryna Yu. Lytovchenko, Fardin Atash Bar \\ UKRAINIAN MEDICAL STOMATOLOGICAL ACADEMY, POLTAVA, UKRAINA
}

\begin{abstract}
The aim: Was to evaluate clinical data after the use of pimecrolimus ( $1 \%$ cream "Elidel") in patients with mild and moderate severity of atopic cheilitis, according to modern therapeutic requirements. There was an algorithm of treatment the patients with cheilitis proposed it based on the data from literary sources and personal clinical experience. Materials and methods: 22 patients with atopic cheilitis aged from 19 to 40 agreed on a clinical examination in accordance with the protocol of the study. Patients were prescribed "Elidel" in the form of $1 \%$ cream for lubrication of the affected areas of the skin and lips, and antihistamine "Erius", for the normalization of the general condition used sedatives and vitamins after consultation of specialists in the general profile.

Results: Patients of both groups during the re-examination after 3,7,10 days recorded a positive dynamics of the red border of the lips and skin: a significant reduction in the inflammatory process, normalization of indicators of general blood analysis, improvement in the overall quality of life of patients.

Conclusions: The results of treatment allow to consider $1 \%$ cream "Elidel" (pimecrolimus) as a preparation of choice in the complex treatment of patients with atopic cheilitis of mild and moderate severity.
\end{abstract}

KEY WORDS: atopic cheilitis, treatment

\section{INTRODUCTION}

Atopic cheilitis (cheilitis atopicalis) - AC is a chronic inflammatory recurrent disease of the lips. According to literary sources, AC affects up to $25 \%$ of children and $2-10 \%$ of adults, the incidence rate in the last 30 years has grown 2-3 times in developed countries. The disease is a symptom of atopic dermatitis or neurodermatitis and has a significant influence on the quality of life of both patients and members of their families $[1,2]$.

The pathogenesis of this disease is still not thoroughly studied, but there is an opinion that the disease occurs as a result of a complex interaction between the violation of the barrier function of the mucous membrane and skin, immune dysfunction and environmental factors or agents of infectious origin. The break of the epithelial barrier leads to the loss of transepithelial fluid, increased sensitivity to infectious and allergic agents. In most cases, AC is characterized by IgE, hypersecretion and violation of cytokine regulation in the ratio of Th1 / Th 2 -lymphocytes, determined deficiency of T-lymphocyte suppressors, disruption of the processes of apoptosis. Clinical symptomatology is caused by allergic inflammation with infiltration by T-lymphocytes and eosinophils. The hyperactive condition of the immune cellular chain in the cascade of interaction between inflammatory infiltrate cells, blood vessels and keratocytes is a key factor in the development of the disease and its clinical manifestations $[3,4]$.

Since AC is a chronic recurrent disease, its clinical management requires comprehensive, long-term therapy. The task is to reduce symptoms, to restore the broken epithe- lial barrier and to enhance the quality of life. In addition, treatment should be aimed at the regulation of immune dysfunction, preventing progression of the disease and prolonging the remission period [4].

As a rule, the basic standard AC therapy includes: facial skin and lips care, elimination contacting factors that trigger aggravation; maintenance therapy in the form of mitigating agents that restore barrier function of the skin and mucous membrane; anti-inflammatory therapy by the use of topical corticosteroids (TCs) and topical calcineurin inhibitors (TCI) $[5,6]$.

For a long time (more than 20 years), in our practice we used TCI - hydrocortisone acetate (1\%) or hydrocortisone butyrate $(0.1 \%)$ as applications for the affected skin of the face and red border of the lips [2].

Now, according to the clinical guidelines of the state expert center (2016) at the Ministry of Health of Ukraine, we use topical calcineurin inhibitors (TCI). It is a non-steroidal immune modulator - tacrolimus ("Protopic") in the form of $0.03 \%$ and $0.1 \%$ ointment and pimecrolimus ("Elidel") in the form of $1 \%$ cream. TICs have a more specific mechanism of action, they selectively suppress the activation of T-cells, mast cells, and the formation of anti-inflammatory cytokines.

\section{THE AIM}

The aim of our study was to evaluate clinical data after the use of pimecrolimus ( $1 \%$ cream "Elidel") in patients with mild and moderate severity of atopic cheilitis, according to 
modern therapeutic requirements. There was an algorithm of treatment the patients with cheilitis proposed it based on the data from literary sources and personal clinical experience.

\section{MATERIALS AND METHODS}

22 patients with atopic cheilitis aged from 19 to 40 agreed on a clinical examination in accordance with the protocol of the study. 13 patients were diagnosed with atopic cheliitis of light severity and isolated lesion of lips was observed. Anamnesis of these patients' states that they do not visit doctor regularly due to this pathology. At first, according to the prescription and later independently apply corticosteroid ointments until the disappearance or reduction of symptoms of the disease. In nine patients from $2^{\text {nd }}$ group lesions of the lips, skin of the upper limbs and eyelids were detected. They noticed itching, peeling of the lips and damaged skin. They are treated continuously, and, as a rule, using hormones in the dosage form of ointments. The red border in all patients was congested hyperemic, squamous, lichenization and infiltration of the skin in the corners of the mouth were noted. General blood analysis stated lymphocytosis and eosinophilia in all patients. Concomitant pathology was noted in $63.5 \%$ of patients, prevalence of pathology of the gastrointestinal tract, vasomotor dyscrasia and allergic conditions. 82\% of patients with atopic cheilitis complained of life quality deterioration, to be exact, that the disease affects daily life, learning, social communication. Patients are anxious, depressed due to skin and lips lesions. Intensive itching, which lasts throughout the day and intensifies at night, leads to insomnia in $40.9 \%$ of patients.

Patients in both groups were prescribed "Elidel" in the form of $1 \%$ cream for lubricating the affected areas of the skin and lips, and as an antihistamine, a long-acting third-generation drug "Erius" in the form of tablets for intraoral administration. In which active substance is desloratadine with triple (antihistamine, anti-allergic and anti-inflammatory) effect. This choice was not accidental. According to the manufacturer, "Erius" suppresses the cascade of various reactions that underlie allergic inflammation, such as: the secretion of proinflammatory cytokines, including IL-4, IL-6, IL-8, IL-13; the secretion of proinflammatory chemokines such as RANTES; production of superoxide anion activated polymorphonuclear neutrophils; adhesion and chemotaxis of eosinophils; IgE-dependent release of histamine, prostaglandin D2 and leukotriene $\mathrm{C} 4$.

In addition, to normalize the general condition, sedative and vitamin preparations were used after consultation by general practitioners.

The studies were carried out in compliance with the main provisions of the "Rules of Ethical Principles for Conducting Scientific Medical Research with Human Participation", approved by the Declaration of Helsinki (1964-2013), ICH GCP (1996), EEC Directive No. 609 (dated 24.11.1986), orders of the Ministry of Health of Ukraine No. 690 dated
September 23, 2009, No. 944 dated December 14, 2009, No. 616 dated August 3, 2012. For participation in the study, patients signed the form of "Voluntary informed consent of the patient to participate in the study".

\section{RESULTS AND DISCUSSION}

Patients in both groups during repeated inspection after 3 , 7 , and 10 days showed a positive dynamics of normalization of the condition of the red border of the lips and skin. Patients of the $1^{\text {st }}$ group noticed an improvement after 3 days of the usage of $1 \%$ of the "Elidel" cream for a number of indicators - redness, itching and partial peeling of the red border of the lips disappeared.

Patients of the $2^{\text {nd }}$ group on the $3^{\text {rd }}$ day of treatment itching and redness disappeared, on the $7^{\text {th }}$ day, infiltration and peeling of the red border of the lips disappeared, on the $10^{\text {th }}$, the phenomena of lichenization significantly decreased.

In both groups, positive dynamics was noted in the general blood test, a significant decrease in the inflammatory process clinics and a significant improvement in the quality of life of the patients.

The obtained results made it possible to propose an algorithm for the treatment of patients with atopic cheilitis, which is performed after oral cavity sanitation as part of complex therapy (allergen elimination, diet, use of softening cosmetic products) as follows:

- Carefully clean the skin and red border of lips with antiseptic;

- apply a thin layer of $1 \%$ cream of "Elidel" on the affected skin and red border of the lips twice a day until the symptoms disappear completely;

- prescribe as an antihistamines drug "Erius" (5 mg) 1 tablet once a day (the duration of treatment is determined by the course and severity of the disease);

- recommend the use of a softening cream for red border and face skin at night;

- educate patients for skin and lips care (avoid contact with irritants and allergens).

"Elidel" once a day for 3 months on those areas where there were elements of lesions and use of moisturizing and softening creams for the skin, hygienic lipstick for the red border of the lips.

\section{CONCLUSIONS}

Thus, atopic cheilitis is a disease requiring complex longterm therapy aimed at regulation of immune dysfunction and consists of the symptoms mitigation, the epithelial barrier restoration, the disease progression prevention, and extension of the remission period.

The results of treatment allow to consider $1 \%$ cream "Elidel" (pimecrolimus) as a preparation of choice in the complex treatment of patients with atopic cheilitis of mild and moderate severity.

The proposed algorithm for treatment of atopic cheilitis is easy to implement, it is directed primarily at the elements of pathogenesis, which allows to control the symptoms of 
the disease (itching, edema, erythema), prevents the development of complications (transition to the eczematous form), contributes to the restoration of affected areas of the skin and red borders of the lips, and also significantly improves the quality of life of this contingent of patients.

\section{REFERENCES}

1. Savychuk N.0., Solomoniuk M.M. Osoblyvosti kliniki ta factory ryzyku vynyknennya atopichnogo heilitu [Clinical features and risk factors for atopic cheilitis]. Liky Ukraiiny.2004;1:79-81. (in Ukrainiane).

2. Ilenko N.M., Nikolishyna E.V. Osoblyvosti likuvannia atopichnogo heilitu [Features of treatment of atopic cheilitis]. Aktualni pytannia ta problemy rozvytku stomatologiii na suchasnomu etapi. Zbirnyk naukovykh prats. Poltava; 2011:100-101. (in Ukrainiane).

3. Protsenko T.V. Dyfferentsyalnyi podhod k naruzhnoi terapiii I uhodu za kozhei bolnykh atopicheskim dermatitom [Differential approach to external therapy and skin care for patients with atopic dermatitis]. Ukraiinskyi zhurnal dermatologiii, venerologiii, kosmetologiii. 2007;2 (25):8-11. (in Russian).

4. Stremchuk M.V. Poshuk efektyvnykh terapevtychnykh zakhodiv zagalnoii I mistsevoii diii pry likuvanni ditei, hvorykh na atopichnyi heilit [Finding effective therapeutic measures of general and local action in the treatment of children with atopic cheilitis]. Profilaktyka ta dytiacha stomatologiia. 2014;2(11):25-28. (in Ukrainiane).

5. Rybalov 0.V., Petruschanko T.O., Lytovchenko I.Yu. Guby ta ih zahvoruvannya [Lips and their diseases]. Navchalnyi posibnyk. Poltava. 2018: 135. (in Ukrainiane).

6. Kalyuzhnaia L.D. Pryntsypialno novoie napravleniie v naruzhnoi terapii atopicheskogo dermatiata [A fundamentally new direction in the external treatment of atopic dermatitis]. Ukraiinskyi zhurnal dermatologiii, venerologiii, kosmetologiii. 2005;1:42-45. (in Russian).
The publication is a fragment of the research paper "Mechanisms of influence of pathogenic factors on the dental status of persons with somatic pathology, ways of their correction and blocking" No. 0115U001138 (2015-2019); Department of Therapeutic Dentistry of UMSA.

\section{ORCID and contributionship:}

Nataliya M. Ilenko: 0000-0001-7293-0432 A,B,C,D,E,F

Ella V. Nikolishyna: 0000-0001-7345-4183 ${ }^{A, B, C, D}$

Iryna Yu. Lytovchenko: 0000-0002-1001-5404 $4^{A, B, C, D}$

Fardin Atash Bar: 0000-0003-3184-6271 ${ }^{B}$

\section{Conflict of interest:}

The Authors declare no conflict of interest.

\section{CORRESPONDING AUTHOR Iryna Yu. Lytovchenko}

Poltava Ukrainian medical stomatological academy

23 Shevchenko st., 36011 Poltava, Ukraina

tel: $+38(0532) 561237$

e-mail: Iytovchenko.iryna@gmail.com

Received: 15.03 .2020

Accepted:05.11.2020

A - Work concept and design, B - Data collection and analysis, C - Responsibility for statistical analysis, D-Writing the article, $\mathbf{E}$-Critical review, $\mathbf{F}$ - Final approval of the article 